\title{
PENGARUH TUGAS PERKEMBANGAN KELUARGA TERHADAP KEPUASAN PERKAWINAN IBU YANG BARU MEMILIKI ANAK PERTAMA
}

\author{
Rahmaita $^{\left.1^{*}\right)}$, Diah Krisnatuti², Lilik Noor Yuliati ${ }^{2}$ \\ ${ }^{1}$ Program Studi Pendidikan Kesejahteraan Keluarga, Fakultas Teknik, Universitas Negeri Jakarta, Jakarta 13220, \\ Indonesia \\ ²Departemen IImu Keluarga dan Konsumen, Fakultas Ekologi Manusia, Insitut Pertanian Bogor, \\ Bogor 16680, Indonesia \\ *) E-mail: rahma88hrp@gmail.com
}

\begin{abstract}
Abstrak
Penelitian ini bertujuan untuk menganalisis pengaruh karakteristik dan tugas perkembangan keluarga terhadap kepuasan perkawinan ibu yang baru memiliki anak pertama. Desain penelitian ini menggunakan cross sectional yang dilakukan pada 120 ibu dari keluarga yang baru memiliki anak pertama usia di bawah dua tahun. Data dianalisis menggunakan regresi linier berganda. Capaian keseluruhan dari tugas perkembangan keluarga yaitu 67,30 yang menunjukkan bahwa tugas perkembangan keluarga telah cukup dipenuhi. Hasil menunjukkan bahwa semakin tinggi pendapatan per kapita keluarga dan semakin bertambah usia ayah maka semakin baik tugas perkembangan dimensi orang tua. Sementara itu, semakin bertambah usia ibu dan usia ayah serta usia pernikahan yang lebih lama maka semakin baik tugas perkembangan keluarga pada dimensi anak. Selain itu, semakin tinggi pendidikan ibu, usia pernikahan yang semakin lama, dan semakin baik tugas perkembangan keluarga (baik pada dimensi orang tua maupun anak) maka kepuasan perkawinan semakin tinggi. Kepuasan perkawinan dipengaruhi oleh tugas perkembangan keluarga. Penelitian ini menegaskan kembali perlunya keluarga untuk dapat memenuhi tugas perkembangannya sesuai dengan tahapan keluarga yang sedang dilalui.
\end{abstract}

Kata kunci: anak pertama, dimensi anak, dimensi orang tua, kepuasan perkawinan, tugas perkembangan keluarga

\section{The Effects of Family Developmental Tasks on Marital Satisfaction on First-Time Mothers}

\begin{abstract}
This study aimed to analyze the influence of family characteristics and family developmental tasks on marital satisfaction of first-time mothers. This was a cross-sectional study involving 120 first-time mothers with a child aged less than two years old. Data were analyzed using multiple linear regression. The average scores of the overall family developmental task were 67,30 , indicating that the developmental task of the family has been adequately fulfilled. The results showed that the increase in a family per capita income and age of the father, the better the developmental task, specifically on parents dimension. Meanwhile, a family with older mother and father was associated with a higher score of child dimension of the family developmental task. Moreover, the increase in mother's education level, the longer the marriage duration, and the higher score of the family developmental task (on both parents and child dimensions), were associated with higher marital satisfaction. Marital satisfaction was influenced by the developmental task of the family. This research reaffirms the need for families to be able to fulfill their developmental task in accordance with their developmental stages.
\end{abstract}

Keywords: first child, the child dimension, the parent dimension, marital satisfaction, developmental task of family

\section{PENDAHULUAN}

Saat ini banyak pasangan yang kurang dalam mempersiapkan diri untuk memasuki kehidupan berumah tangga, hanya siap untuk menikah namun tidak siap untuk berkeluarga. Akibatnya, tidak jarang pasangan setelah pernikahan mengalami disfungsi keluarga yang berujung pada perceraian. Menurut data Kementerian Agama Republik Indonesia (RI), pada tahun
2013 sebanyak 324.527 pasangan bercerai di Indonesia. Data ini menunjukkan bahwa sudah melebihi angka sepuluh persen dari jumlah perkawinan sebanyak 2.218 .130 pasangan. Ironisnya, perceraian terbanyak terjadi pada usia rumah tangga muda yakni di bawah lima tahun.

Salah satu yang dapat menjadi penyebab dari perceraian yaitu berkurangnya kepuasan 
perkawinan antara suami dan istri. Kepuasan perkawinan merefleksikan secara umum kebahagiaan dan keberfungsian dalam pernikahan seseorang (Schoen et al., 2002). Hawkins (1968) menjelaskan bahwa kepuasan perkawinan adalah perasaan subjektif yang dirasakan pasangan suami atau istri. Kepuasan perkawinan merupakan bentuk persepsi terhadap kehidupan pernikahan seseorang yang diukur dari besar dan kecilnya kesenangan yang dirasakan dalam jangka waktu tertentu (Roach, Frasier, \& Bowten, 1981). Penelitian terdahulu yang dilakukan oleh Zainah et al. (2012) menemukan bahwa pasangan dengan lama pernikahan lebih dari sepuluh tahun memiliki kepuasan yang lebih tinggi.

Berkurangnya kepuasan perkawinan antara suami dan istri juga dapat disebabkan hadirnya anak di tengah-tengah pasangan yang baru membentuk sebuah keluarga. Kehadiran anak dapat menambah sekaligus mengurangi keharmonisan suami-istri, yang mengubah hubungan yang bersifat dwitunggal menjadi tritunggal (Hurlock, 1999). Keluarga yang sedang mengalami masa transisi menjadi orang tua dengan anak pertama usia di bawah dua tahun merupakan masa yang paling kritis dan rentan karena para orang tua akan sadar, mereka harus mengubah pola makan, pola tidur serta pola hubungan suami-istri. Tuntutan sebagai ayah dan ibu akan dirasa semakin berat apabila ayah dan ibu tidak dapat menyesuaikan peran dan tugas perkembangan keluarganya. Hal ini didukung dengan hasil penelitian yang menyatakan bahwa keterlibatan suami/ayah dalam pekerjaan rumah tangga dan pengasuhan anak dapat memberikan pengaruh yang positif terhadap kepuasan perkawinan ibu (Forste \& Fox, 2008). Hal tersebut menunjukkan bahwa pemenuhan tugas perkembangan keluarga memerlukan dukungan baik dari segi materi maupun nonmateri.

Tugas perkembangan yang terpenuhi pada tahapan awal membangun keluarga akan mengarahkan pada tugas-tugas perkembangan selanjutnya dan mengarahkan pada kebahagiaan serta kesuksesan keluarga. Tugas perkembangan bagi keluarga yang baru mempunyai anak pertama merupakan tahap kedua dari delapan tahapan keluarga menurut Duvall (1971). Pada tahap kedua ini ada masalah yang harus dihadapi oleh keluarga yang baru mempunyai anak pertama yang terdiri atas dua dimensi yaitu dimensi anak dan dimensi orang tua. Masalah yang harus dihadapi meliputi pendidikan tentang menjadi orang tua (ibu dan ayah), fokus keluarga, perawatan bayi serta penyesuaian peran baru sebagai orang tua, sehingga pertumbuhan dan perkembangan anak dapat tercapai secara optimal. Pada tahap ini banyak ibu baru yang merasa tidak mampu mengerjakan banyak hal dan akan merasa tertekan, serta ingin lari dari kenyataan. Apabila keluarga tidak berhasil memenuhi tugas perkembangannya maka akan berdampak pada ketidakbahagiaan dan kesulitan dalam menjalankan tugas perkembangan pada tahap selanjutnya. Selain itu, pandangan dan sikap yang sama dari ibu dan pasangan terhadap tumbuh kembang anak dapat memengaruhi kepuasan perkawinan ibu. Dengan demikian, penting melakukan penelitian untuk melihat pengaruh tugas perkembangan keluarga terhadap kepuasan perkawinan ibu yang baru mempunyai anak pertama usia di bawah dua tahun.

Di Indonesia, penelitian terkait kepuasan perkawinan sudah beberapa dilakukan. Penelitian Meliani, Sunarti, \& Krisnatuti (2014) menunjukkan bahwa kepuasan perkawinan dipengaruhi secara signifikan negatif oleh konflik antara pekerjaan dan keluarga. Hanya saja belum ada penelitian yang mengaitkan antara kepuasan perkawinan, khususnya kepuasan perkawinan ibu, dengan tugas perkembangan keluarga baik yang dilihat dari dimensi orang tua maupun dimensi anak. Oleh karenanya, penelitian ini bertujuan untuk mengidentifikasi karakteristik keluarga, tugas perkembangan keluarga, dan kepuasan perkawinan ibu yang baru memiliki anak pertama. Selain itu, penelitian ini juga menganalisis hubungan antarvariabel penelitian dan menganalisis pengaruh karakteristik keluarga dan tugas perkembangan keluarga terhadap kepuasan perkawinan ibu yang baru memiliki anak pertama.

\section{METODE}

Penelitian ini dilakukan menggunakan desain cross sectional. Penelitian ini dilakukan di Kecamatan Cipayung, Kota Depok, Provinsi Jawa Barat. Kota Depok merupakan salah satu kota yang cukup maju dan merupakan salah satu kota penyangga ibu kota. Hanya saja, Kecamatan Cipayung dipilih karena berdasarkan BPS Kota Depok (2011) merupakan kecamatan dengan Indeks Pembangunan Manusia terendah di Kota Depok yang mengindikasikan adanya permasalahan pada pembangunan manusia, termasuk kehidupan keluarga. Penelitian ini dilaksanakan pada bulan April sampai dengan bulan Oktober tahun 2014. 
Populasi dalam penelitian ini adalah seluruh ibu dari keluarga yang memiliki anak pertama usia di bawah dua tahun di kedua kelurahan terpilih. Penelitian ini melibatkan 120 ibu yang dipilih dari populasi penelitian yang dipilih secara acak sebagai responden penelitian. Data primer dalam penelitian ini diperoleh melalui wawancara langsung terhadap responden dengan menggunakan alat bantu kuesioner. Data primer yang dikumpulkan meliputi karakteristik keluarga (usia ayah, usia ibu, usia menikah ayah, usia menikah ibu, usia ibu saat melahirkan anak pertama, pendidikan ayah, pendidikan ibu, pekerjaan ayah, pekerjaan ibu, lama pernikahan, pendapatan keluarga, dan pendapatan per kapita keluarga), tugas perkembangan keluarga, dan kepuasan perkawinan.

Dalam penelitian ini, tugas perkembangan keluarga didefinisikan sebagai serangkaian kewajiban yang harus dipenuhi oleh keluarga selama kehidupannya. Tugas perkembangan keluarga tahap kedua (keluarga dengan anak pertama masih di bawah dua tahun) diukur dengan dua dimensi, yaitu dimensi orang tua dan dimensi anak sesuai konsep Duvall (1971). Dimensi orang tua merujuk pada tugas perkembangan yang harus dipenuhi oleh kedua orang tua (ayah dan ibu). Dimensi ini terdiri atas beberapa indikator, yaitu rekonsiliasi penyesuaian peran, menerima dan menyesuaikan tuntutan sebagai ibu muda, belajar merawat bayi dengan kompeten, membangun dan mempertahankan rutinitas keluarga yang sehat, memberikan kesempatan penuh untuk perkembangan anak, berbagi tanggung jawab orang tua dengan suami, mempertahankan hubungan yang romantis dengan suami, membuat penyesuaian yang memuaskan dengan realitas kehidupan, menjaga kehidupan ibu muda melalui otonomi pribadi, dan mengeksplorasi dan mengembangkan rasa memuaskan menjadi keluarga.

Sementara itu, dimensi anak merujuk pada tugas perkembangan yang seharusnya dituntaskan oleh anak, terdiri atas beberapa indikator, yaitu: mencapai keseimbangan fisiologis setelah kelahiran, belajar untuk mendapatkan kepuasan akan makanan, belajar mengetahui kapan, dimana dan bagaimana BAK dan BAB, belajar untuk mengelola tubuh secara efektif, belajar menyesuaikan dengan orang lain, belajar untuk menyayangi dan disayangi, mengembangkan sistem komunikasi, belajar untuk mengekspresikan dan mengendalikan perasaan, dan menempatkan dasar untuk kesadaran diri.
Instrumen tugas perkembangan keluarga dalam peneliian ini dikembangkan oleh peneliti melalui pendekatan teori perkembangan keluarga Duvall (1971). Instrumen dimensi orang tua terdiri atas 19 pertanyaan dengan nilai Cronbach's alpha 0,660. Sementara itu, instrumen dimensi anak terdiri atas 16 pertanyaan dengan nilai Cronbach's alpha 0,832 . Secara keseluruhan dengan menggabungkan kedua dimensi tersebut maka diperoleh nilai Cronbach's alpha tugas perkembangan keluarga sebesar 0,784. Setiap pertanyaan mempunyai empat pilihan rentang jawaban dari 1=tidak pernah, 2=kadangkadang, 3=sering, dan 4=selalu. Selanjutnya, total nilai yang diperoleh kemudian dihitung indeksnya sehingga diperoleh skor minimum adalah nol dan skor maksimum adalah 100,0. Pengkategorian data yang digunakan adalah interval kelas dengan tiga kategori, yaitu kategori rendah $(0,0-59,0)$, sedang $(60,0-80,0)$, dan tinggi $(81,0-100,0)$.

Selanjutnya, kepuasan perkawinan dalam penelitian ini merupakan perasaan subjektif yang dirasakan oleh ibu terhadap perkawinannya. Instrumen kepuasan perkawinan terdiri atas sepuluh dimensi, yaitu masalah kepribadian, kesetaraan peran, komunikasi, penyelesaian konflik, pengelolaan keuangan, aktifitas bersama, relasi seksual, anak dan pernikahan, keluarga dan teman, dan orientasi religius. Instrumen kepuasan perkawinan yang digunakan dalam penelitian ini menggunakan alat ukur ENRICH (Evaluation and Nurturing Relationship Issues, Communication and Happiness) Marital Satisfaction (EMS) dari Fower dan Olson (1993). Instrumen ini terdiri atas 15 pertanyaan dan memiliki nilai Cronbach's alpha sebesar 0,885 . Setiap pertanyaan mempunyai lima pilihan rentang jawaban dari $1=$ sangat tidak setuju, 2=tidak setuju, 3=biasa saja, 4=setuju, dan 5=sangat setuju. Selanjutnya, total nilai yang diperoleh dihitung indeksnya dan dikategorikan berdasarkan cut off point menjadi tiga kategori, yaitu rendah $(0,0-59,0)$, sedang $(60,0-80,0)$, dan tinggi $(81,0-100,0)$.

Analisis data yang digunakan dalam penelitian ini yaitu analisis deskriptif dan inferensial. Analisis deskriptif digunakan untuk mengidentifikasi karakteristik keluarga, tugas perkembangan keluarga dimensi anak dan dimensi orang tua, dan kepuasan perkawinan ibu. Analisis inferensial yang digunakan dalam penelitian ini meliputi uji hubungan dan analisis regresi linear berganda. Uji hubungan digunakan untuk melihat hubungan antarvariabel. Sementara itu, analisis regresi linear 
berganda digunakan untuk menganalisis pengaruh karakteristik keluarga dan tugas perkembangan keluarga terhadap kepuasan perkawinan ibu.

\section{HASIL}

\section{Karakteristik Keluarga}

Hasil penelitian karakteristik keluarga menunjukkan bahwa rata-rata usia ayah dan ibu pada penelitian ini adalah 29,10 dan 25,60 tahun. Usia ini termasuk dalam kelompok usia dewasa muda menurut Hurlock (1999), yang mana usia dewasa muda berada rentang usia antara 18 hingga 40 tahun. Rata-rata usia ayah dan ibu menikah yaitu 26,40 tahun dan 22,80 tahun. Rata-rata usia ibu melahirkan yaitu pada usia 24,40 tahun dengan usia minimum dan maksimum sebesar 16 tahun dan 41 tahun.

Rata-rata lama pendidikan yang ditempuh oleh ayah dan ibu sebesar 11,50 tahun dan 11,40 tahun yaitu setara dengan SMA. Rata-rata lama pernikahan dalam penelitian ini adalah 2,80 tahun dengan lama pernikahan minimum 1 tahun dan maksimum 15 tahun. Sementara itu, rata-rata pendapatan per kapita yang dimiliki oleh keluarga yaitu sebesar Rp1.080.611,00 dan pendapatan per kapita terendah yang dimiliki oleh keluarga yaitu sebesar Rp333.333,00 yang dapat dikatakan bahwa penghasilan per kapita berada di atas garis kemiskinan Kota Depok tahun 2012 yaitu sebesar Rp310.279,00.

Berdasarkan jenis pekerjaan yang dimiliki oleh ayah dan ibu dapat dipaparkan beberapa jenis pekerjaan yang dimiliki oleh ibu dan ayah yang terdiri atas tidak bekerja atau ibu rumah tangga (IRT); Pegawai Negeri Sipil (PNS) yang meliputi guru, dosen, Tentara Nasional Indonesia (TNI), Polisi, pegawai instansi milik negara, perawat; karyawan yaitu pegawai swasta yang memiliki gaji tetap setiap bulannya; wiraswasta atau memiliki usaha sendiri; dan buruh yaitu pekerjaan dengan penghasilan tidak tetap (misalnya petani, tukang). Pekerjaan yang paling banyak dimiliki oleh responden adalah sebagai ibu rumah tangga sebesar $(50,0 \%)$ dan pekerjaan kedua tertinggi yaitu sebagai karyawan $(32,5 \%)$. Lebih dari separuh jenis pekerjaan yang dimiliki suami adalah sebagai karyawan dan persentase terkecil pekerjaan suami yaitu sebagai PNS.

\section{Tugas Perkembangan Keluarga}

Tugas-tugas perkembangan keluarga terjadi apabila keluarga sebagai sebuah unit berupaya memenuhi tuntutan-tuntutan perkembangan mereka secara individual. Tugas-tugas perkembangan keluarga juga diciptakan oleh tekanan-tekanan komunitas terhadap keluarga dan anggotanya untuk menyesuaikan diri dengan harapan-harapan kelompok acuan keluarga dan masyarakat yang lebih luas.

Hasil penelitian menunjukkan bahwa rata-rata capaian keseluruhan dari tugas perkembangan keluarga adalah sebesar 67,3 (Tabel 1). Temuan ini menunjukkan bahwa rata-rata ibu dalam penelitian ini telah menilai bahwa keluarga mereka telah cukup baik menyelesaikan tugas perkembangannya. Sementara itu, apabila dilihat pada masingmasing dimensi, hasil penelitian menunjukkan bahwa rata-rata tugas perkembangan keluarga pada dimensi orang tua adalah sebesar 61,9 (kategori sedang), dengan capaian paling tinggi $(80,0)$ yaitu berbagi tanggung jawab sebagai orang tua dengan suami. Sementara itu, capaian yang masih rendah atau rata-rata kurang dari 60,0 tampak pada indikator belajar merawat bayi dengan kompeten $(57,8)$, memberi kesempatan penuh untuk perkembangan anak $(56,8)$ mempertahankan hubungan yang romantis dengan suami $(41,7)$, dan menjaga kehidupan ibu muda melalui otonomi pribadi $(46,5)$.

Selain itu, berdasarkan hasil penelitian juga menemukan bahwa rata-rata capaian dari tugas perkembangan keluarga dimensi anak secara keseluruhan adalah sebesar 73,10. Hasil ini juga menunjukkan bahwa rata-rata anak di bawah usia dua tahun dalam penelitian ini telah memenuhi tugas perkembangannya dengan cukup baik. Pada kelompok anak usia 0 hingga 1 tahun, capaian terendah tugas perkembangannya adalah pada aspek belajar untuk mengekspresikan dan mengendalikan perasaan dengan rata-rata capaian sebesar 57,45 dan pada anak usia 0 hingga 2 tahun yaitu pada aspek memiliki kemampuan terhadap kesadaran diri dengan rata-rata capaian sebesar 67,90 . Sementara itu, pada kedua kelompok usia capaian yang tertinggi tampak pada aspek belajar mengetahui, bagaimana, dimana, dan kapan anak melakukan BAK/BAB (eliminasi).

Apabila dikategorikan berdasarkan cut-off point capaian tugas perkembangan keluarga, hasil penelitian menunjukkan bahwa sebanyak tiga dari lima ibu termasuk dalam kategori sedang. Sementara itu, sebanyak 24,2 persen ibu berada pada kategori rendah dan sebanyak 15,8 persen ibu yang berada pada kategori tinggi. 
Tabel 1 Nilai rata-rata dan standar deviasi tugas perkembangan keluarga

\begin{tabular}{|c|c|c|}
\hline Tugas Perkembangan Keluarga & \multicolumn{2}{|c|}{$\begin{array}{c}\text { Rata-rata } \pm \\
\text { Standar deviasi }\end{array}$} \\
\hline $\begin{array}{l}\text { a. Rekonsiliasi penyesuaian } \\
\text { peran }\end{array}$ & \multicolumn{2}{|c|}{$73,20 \pm 21,26$} \\
\hline $\begin{array}{l}\text { b. Menerima dan menyesuaikan } \\
\text { tuntutan sebagai ibu muda }\end{array}$ & \multicolumn{2}{|c|}{$69,30 \pm 24,27$} \\
\hline $\begin{array}{l}\text { c. Belajar merawat bayi dengan } \\
\text { kompeten }\end{array}$ & \multicolumn{2}{|c|}{$57,80 \pm 26,76$} \\
\hline $\begin{array}{l}\text { d. Membangun dan } \\
\text { mempertahankan rutinitas } \\
\text { keluarga yang sehat }\end{array}$ & \multicolumn{2}{|c|}{$60,40 \pm 27,40$} \\
\hline $\begin{array}{l}\text { e. Memberi kesempatan penuh } \\
\text { untuk perkembangan anak }\end{array}$ & \multicolumn{2}{|c|}{$56,80 \pm 29,21$} \\
\hline $\begin{array}{l}\text { f. Berbagi tanggung jawab } \\
\text { sebagai orang tua dengan } \\
\text { suami }\end{array}$ & \multicolumn{2}{|c|}{$80,00 \pm 23,71$} \\
\hline $\begin{array}{l}\text { g. Mempertahankan hubungan } \\
\text { yang romantis dengan suami }\end{array}$ & \multicolumn{2}{|c|}{$41,70 \pm 41,66$} \\
\hline $\begin{array}{l}\text { h. Membuat penyesuaian yang } \\
\text { memuaskan dengan realitas } \\
\text { kehidupan }\end{array}$ & \multicolumn{2}{|c|}{$60,80 \pm 30,64$} \\
\hline $\begin{array}{l}\text { ehidupan ibu muda } \\
\text { nomi pribadi }\end{array}$ & \multicolumn{2}{|c|}{$46,50 \pm 29,91$} \\
\hline $\begin{array}{l}\text { j. Mengeksplorasi dan } \\
\text { mengembangkan rasa } \\
\text { memuaskan menjadi keluarga }\end{array}$ & \multicolumn{2}{|c|}{$62,40 \pm 33,19$} \\
\hline Dimen & \multicolumn{2}{|c|}{$61,90 \pm 13,75$} \\
\hline & $\begin{array}{c}0-1 \\
\text { tahun }\end{array}$ & $\begin{array}{c}1-2 \\
\text { tahun }\end{array}$ \\
\hline $\begin{array}{l}\text { a. Menc } \\
\text { fisiols }\end{array}$ & $\begin{array}{c}76,12 \pm \\
27,35\end{array}$ & $\begin{array}{l}81,00_{ \pm} \\
30,05\end{array}$ \\
\hline $\begin{array}{l}\text { b. Belaja } \\
\text { kepua }\end{array}$ & $\begin{array}{c}67,88 \pm \\
29,48\end{array}$ & $\begin{array}{c}84,71 \pm \\
18,91\end{array}$ \\
\hline $\begin{array}{l}\text { c. Belajar mengetahui } \\
\text { bagaimana, dimana dan } \\
\text { kapan terjadi eliminasi }\end{array}$ & $\begin{array}{c}81,40_{ \pm} \\
27,48\end{array}$ & $\begin{array}{c}88,58 \pm \\
23,47\end{array}$ \\
\hline $\begin{array}{l}\text { d. Belaj } \\
\text { tubul }\end{array}$ & $\begin{array}{c}64,05 \pm \\
28,94\end{array}$ & $\begin{array}{l}77,92 \pm \\
22,39\end{array}$ \\
\hline $\begin{array}{l}\text { e. Belajar meny } \\
\text { dengan orans }\end{array}$ & $\begin{array}{c}67,28 \pm \\
25,25\end{array}$ & $\begin{array}{c}77,98 \pm \\
20,24\end{array}$ \\
\hline $\begin{array}{l}\text { f. Belajar untuk menyayangi } \\
\text { dan disayangi }\end{array}$ & $\begin{array}{c}63,47 \pm \\
23,61\end{array}$ & $\begin{array}{r}81,69 \\
+18,61\end{array}$ \\
\hline $\begin{array}{l}\text { g. Mengembangkan sistem } \\
\text { komunikasi }\end{array}$ & $\begin{array}{l}61,98 \pm \\
22,63\end{array}$ & $\begin{array}{c}78,73 \pm \\
19,93\end{array}$ \\
\hline $\begin{array}{l}\text { h. Belajar untuk } \\
\text { mengekspresikan dan } \\
\text { mengendalikan perasaan }\end{array}$ & $\begin{array}{c}57,45 \pm \\
30,29\end{array}$ & $\begin{array}{c}80,15 \pm \\
21,53\end{array}$ \\
\hline $\begin{array}{l}\text { i. Memiliki kemampuan } \\
\text { terhadap kesadaran diri }\end{array}$ & $\begin{array}{c}60,40 \pm \\
32,69\end{array}$ & $\begin{array}{r}74,47 \pm \\
26,32\end{array}$ \\
\hline Dimensi anak total & $\begin{array}{l}64,93 \pm \\
17,09\end{array}$ & $\begin{array}{c}79,85 \pm \\
12,03\end{array}$ \\
\hline $\begin{array}{l}\text { Tugas perkembangan keluarga } \\
\text { total }\end{array}$ & \multicolumn{2}{|c|}{$67,30 \pm 11,20$} \\
\hline
\end{tabular}

\section{Kepuasan Perkawinan}

Hasil analisis variabel kepuasan perkawinan responden yang ditunjukkan pada Tabel 2 bahwa rata-rata capaian keseluruhan dari kepuasan perkawinan yaitu sebesar 63,10.
Tabel 2 Nilai rata-rata dan standar deviasi capaian kepuasan perkawinan ibu

\begin{tabular}{lc}
\hline Kepuasan Perkawinan & $\begin{array}{c}\text { Rata-rata } \pm \text { Standar } \\
\text { deviasi }\end{array}$ \\
\hline Masalah kepribadian & $62,60 \pm 22,11$ \\
Kesetaraan peran & $71,30 \pm 26,85$ \\
Komunikasi & $63,00 \pm 18,89$ \\
Penyelesaian konflik & $66,00 \pm 31,88$ \\
Pengelolaan keuangan & $52,00 \pm 29,15$ \\
Aktifitas bersama & $68,50 \pm 32,49$ \\
Relasi seksual & $69,00 \pm 29,88$ \\
Anak dan pernikahan & $61,90 \pm 22,33$ \\
Keluarga dan teman & $54,00 \pm 33,21$ \\
Orientasi religious & $75,20 \pm 26,22$ \\
Kepuasan perkawinan total & $63,10 \pm 12,65$ \\
\hline
\end{tabular}

Dimensi kepuasan perkawinan dengan skor rata-rata yang paling tinggi capaiannya adalah orientasi religius yaitu ibu merasa senang tentang bagaimana keluarga mempraktikkan keyakinan agama dan nilai-nilai dalam sebuah keluarga $(75,20)$. Sementara itu, capaian terendah $(52,00)$ adalah pengelolaan keuangan yang dapat dikatakan ibu masih kurang bahagia dengan posisi keuangan keluarga dan cara ibu dan ayah dalam membuat keputusan keuangan. Selain itu, rata-rata terendah $(54,00)$ juga berkaitan dengan kebutuhan yang tidak terpenuhi dalam hubungan dengan keluarga dan teman.

Tabel 3 menunjukkan bahwa skor indeks kepuasan perkawinan minimum adalah 30,00 dan skor maksimum adalah 88,00. Apabila kepuasan perkawinan dinilai berdasarkan kategori cut-off point ditemukan bahwa sekitar tiga dari sepuluh ibu tingkat kepuasan perkawinannya berada pada kategori rendah. Hasil lain juga menunjukkan bahwa enam dari sepuluh ibu telah mencapai kepuasan perkawinan kategori sedang. Hasil ini menunjukkan bahwa lebih dari separuh jumlah ibu $(60,8 \%)$ telah merasa cukup terhadap kepuasan perkawinan ibu dengan suami walaupun baru memiliki anak pertama yang berusia di bawah dua tahun. Hanya saja, penelitian ini hanya menemukan 7,5 persen ibu yang memiliki kepuasan perkawinan yang tinggi atau baik.

Tabel 3 Sebaran kategori kepuasan perkawinan ibu

\begin{tabular}{lrr}
\hline Kategori Kepuasan Perkawinan & \multicolumn{1}{c}{$\mathrm{n}$} & \multicolumn{1}{c}{$\%$} \\
\hline Rendah $(0,0-60,0)$ & 38 & 31,7 \\
Sedang $(61,0-80,0)$ & 73 & 60,8 \\
Tinggi $\quad(81,0-100,0)$ & 9 & 7,5 \\
Total & 120 & 100,0 \\
Minimum-maksimum & $30,00-88,00$ \\
\hline
\end{tabular}

Keterangan: $n=$ jumlah, \%=persentase 


\section{Hubungan Karakteristik Keluarga dan Tugas Perkembangan Keluarga dengan Kepuasan Perkawinan}

Hasil uji hubungan menunjukkan bahwa tugas perkembangan keluarga dimensi orang tua mempunyai hubungan positif dengan pendapatan per kapita dan usia ayah. Artinya, semakin tinggi pendapatan per kapita keluarga dan semakin tinggi usia ayah maka semakin baik tugas perkembangan keluarga dimensi orang tua. Sementara itu, tugas perkembangan keluarga dimensi anak berhubungan positif signifikan dengan usia ibu, usia ayah, dan lama pernikahan. Hasil ini dapat diartikan bahwa semakin tinggi usia ibu dan ayah serta semakin lama pernikahan maka semakin baik pula tugas perkembangan anaknya.

Selain itu, usia ibu, usia ayah, pendidikan ibu, dan lama pernikahan mempunyai hubungan positif terhadap kepuasan perkawinan. Artinya, semakin tinggi usia ayah dan ibu, pendidikan ibu, dan semakin lama pernikahan maka kepuasan perkawinan juga semakin meningkat atau baik. Hasil analisis juga menunjukkan terdapat hubungan yang positif signifikan antara tugas perkembangan keluarga dimensi orang tua dan dimensi anak dengan kepuasan perkawinan. Temuan tersebut menegaskan bahwa semakin baik tugas perkembangan keluarga baik dari dimensi orang tua maupun anak maka semakin tinggi kepuasan perkawinan yang dirasakan oleh ibu (Tabel 4).

\begin{tabular}{|c|c|c|c|}
\hline \multirow[t]{2}{*}{ Variabel } & \multicolumn{2}{|c|}{$\begin{array}{c}\text { Tugas } \\
\text { Perkembangan } \\
\text { Keluarga }\end{array}$} & \multirow{2}{*}{$\begin{array}{l}\text { Kepuasan } \\
\text { Perkawinan }\end{array}$} \\
\hline & $\begin{array}{l}\text { Dimensi } \\
\text { orang tua }\end{array}$ & $\begin{array}{l}\text { Dimensi } \\
\text { Anak }\end{array}$ & \\
\hline Usia ibu & 0,162 & $0,316^{\star *}$ & $0,269^{* *}$ \\
\hline Pendidikan ibu & 0,117 & 0,036 & $0,203^{*}$ \\
\hline Status & 0,168 & $-0,083$ & 0,076 \\
\hline \multicolumn{4}{|l|}{ Bekerja ibu } \\
\hline Usia ayah & $0,192^{*}$ & $0,387^{\star *}$ & $0,285^{\star \star}$ \\
\hline $\begin{array}{l}\text { Pendidikan } \\
\text { ayah }\end{array}$ & 0,142 & $-0,011$ & 0,161 \\
\hline $\begin{array}{l}\text { Pendapatan } \\
\text { per kapita }\end{array}$ & $0,267^{\star *}$ & $-0,074$ & 0,133 \\
\hline $\begin{array}{l}\text { Lama } \\
\text { pernikahan }\end{array}$ & 0,138 & $0,288^{\star *}$ & $0,185^{*}$ \\
\hline $\begin{array}{l}\text { Dimensi } \\
\text { orang tua }\end{array}$ & & $0,250^{* *}$ & $0,443^{* *}$ \\
\hline Dimensi anak & - & - & $0,313^{\star *}$ \\
\hline
\end{tabular}

\section{Pengaruh Karakteristik Keluarga dan Tugas Perkembangan Keluarga terhadap Kepuasan Perkawinan Ibu}

Hasil uji analisis regresi menunjukkan nilai Adjusted $R$ Square sebesar 0,247. Hasil ini berarti bahwa model ini mampu menjelaskan pengaruh karakteristik keluarga dan tugas perkembangan keluarga (dimensi orang tua dan dimensi anak) terhadap kepuasan perkawinan ibu sebesar 24,7 persen. Sementara itu, sisanya sebanyak 75,3 persen dipengaruhi variabel lain yang tidak terdapat dalam model. Hasil analisis juga menunjukkan bahwa tugas perkembangan dimensi orang tua berpengaruh positif dan signifikan terhadap kepuasan perkawinan $(\beta=0,364, p=0,000)$. Hal ini menunjukkan bahwa setiap peningkatan capaian tugas perkembangan dimensi orangtua menyebabkan peningkatan tingkat kepuasan perkawinan yang dimiliki ibu. Selain itu, tugas perkembangan dimensi anak juga berpengaruh terhadap kepuasan perkawinan ibu $(\beta=0,224$, $p=0,026$ ). Hal ini menunjukkan bahwa semakin baik capaian tugas perkembangan dimensi anak, maka tingkat kepuasan perkawinan ibu akan semakin meningkat. Hasil analisis pengaruh karakteristik keluarga dan tugas perkembangan keluarga terhadap kepuasan perkawinan disajikan pada Tabel 5.

Tabel 5 Hasil uji pengaruh karakteristik keluarga dan tugas perkembangan keluarga terhadap kepuasan perkawinan

\begin{tabular}{|c|c|c|c|}
\hline \multirow[b]{2}{*}{ Variabel } & \multicolumn{3}{|c|}{ Kepuasan perkawinan } \\
\hline & B & $\begin{array}{c}\beta \\
\text { (Beta) }\end{array}$ & Sig. \\
\hline Konstanta & 16,598 & & 0,044 \\
\hline Usia ibu (tahun) & 0,285 & 0,103 & 0,249 \\
\hline $\begin{array}{l}\text { Pendidikan ibu } \\
\text { (tahun) }\end{array}$ & 0,705 & 0,131 & 0,156 \\
\hline $\begin{array}{l}\text { Status bekerja ibu } \\
\text { (1=bekerja, } 0=\text { tidak) }\end{array}$ & 0,075 & 0,003 & 0,975 \\
\hline Usia anak (tahun) & $-0,298$ & $-0,149$ & 0,139 \\
\hline $\begin{array}{l}\text { Pendapatan per } \\
\text { kapita (Rp/bulan) }\end{array}$ & $-2,113$ & $-0,009$ & 0,929 \\
\hline $\begin{array}{l}\text { Lama pernikahan } \\
\text { (tahun) }\end{array}$ & 0,748 & 0,118 & 0,201 \\
\hline $\begin{array}{l}\text { Tugas } \\
\text { perkembangan } \\
\text { dimensi orang tua }\end{array}$ & 0,335 & 0,364 & $0,000^{* *}$ \\
\hline $\begin{array}{l}\text { Tugas } \\
\text { perkembangan } \\
\text { dimensi anak }\end{array}$ & 0,173 & 0,224 & $0,026^{*}$ \\
\hline $\mathrm{F}$ & & 5,872 & \\
\hline Sig. & & 0,000 & \\
\hline R Square & & 0,297 & \\
\hline Adjusted R Square & & 0,247 & \\
\hline
\end{tabular}




\section{PEMBAHASAN}

Hasil analisis deskriptif pada penelitian ini menunjukkan bahwa rata-rata usia menikah ayah dan ibu adalah 26,40 dan 22,80 tahun. Hal ini dapat berarti bahwa sebagian besar suami dan istri telah menikah pada batas usia yang ideal menurut program Pendewasaan Usia Perkawinan (PUP) BKKBN, yaitu laki-laki sebaiknya menikah di atas usia 25 tahun dan perempuan di atas 20 tahun.

Hasil capaian yang kurang berkontribusi pada tugas perkembangan keluarga dimensi orang tua yaitu mempertahankan hubungan yang romantis dengan suami. Menurut Guerrero dan Mongeau (2008), hubungan romantis dapat muncul dari pertemanan yang kemudian berkembang menjadi percintaan. Akan tetapi, tidak mudah untuk mempertahankan hubungan romantis yang dimiliki dalam jangka waktu lama, apalagi pasangan suami istri sedang dalam masa penyesuaian akibat kehadiran anak yang masih di bawah usia dua tahun. Kemampuan mempertahankan romantisme antara suami istri merujuk pada kemampuan individu dalam melakukan penetapan, perencanaan dan pengambilan keputusan mengenai hubungan romantis yang sedang dijalani (McCabe \& Barnett, 2000).

Sementara itu, capaian yang paling berkontribusi pada tugas perkembangan keluarga dimensi orang tua yaitu bahwa ibu telah mampu dalam berbagi tanggung jawab dengan suami, serta telah mampu menyesuaikan peran baik sebagai ibu maupun sebagai istri. Penelitian ini menemukan bahwa suami dan istri bersepakat dalam membagi peran dan tugas sehari-hari, bertanggung jawab terhadap peran dan tugas masingmasing dan saling menjaga komitmen bersama. Menurut Hoffman (1984) masyarakat pada umumnya menilai pekerjaan rumah tangga terbatas pada tanggung jawab untuk mempersiapkan makanan, membersihkan, dan mengatur rumah tangga, serta mengasuh anak. Padahal sebagai ibu rumah tangga, ibu juga memiliki tanggung jawab untuk mengembangkan hubungan yang memuaskan bersama keluarga yaitu suami dan anak. Walaupun mungkin terlihat sederhana, pekerjaan sebagai ibu rumah tangga pada kenyataannya cukup berat dan menyita waktu.

Sementara itu, pada capaian tugas perkembangan keluarga dimensi anak, pada kelompok anak usia 0-1 tahun diperoleh hasil rata-rata indeks adalah 64,93 dan 79,85 pada kelompok usia 1-2 tahun. Temuan tersebut mengindikasikan bahwa semakin bertambah kelompok usia anak maka ibu cenderung semakin baik memenuhi tugas perkembangan anak. Kesuksesan keluarga dalam pelaksanaan tugas perkembangan keluarga tidak menutup kemungkinan akan memberikan dukungan dalam perkembangan anak, karena perkembangan anak pada lima tahun pertama merupakan dasar untuk perkembangan selanjutnya.

Hasil penelitian memperlihatkan bahwa lebih dari seperempat ibu mengalami kepuasan perkawinan yang rendah dan lebih dari separuh ibu berada pada kategori sedang. Hal ini menunjukkan bahwa tidak semua indikator kepuasan perkawinan dapat dirasakan oleh ibu dari keluarga dengan anak pertama di bawah usia dua tahun. Indikator yang tidak dapat dipenuhi oleh ibu yaitu pada dimensi pengelolaan keuangan. Menurut Hurlock (1999), konsep yang tidak realistis seperti harapan-harapan tentang kemampuan keuangan untuk memiliki barang-barang yang dianggap penting dan ketidakmampuan untuk memenuhi biaya hidup dapat menjadi masalah yang timbul dalam perkawinan. Hal ini sesuai dengan pendapat Furstenberg (diacu dalam Wiliams, Sawyer \& Wahlstrom, 2006) bahwa konflik keuangan biasanya terjadi karena adanya perbedaan harapan dalam masingmasing peran yang dijalankan oleh pasangan. Keterbukaan dalam hal pengelolaan dan pengeluaran keuangan akan membuat pasangan lebih bahagia dalam perkawinan. Selain itu, rata-rata capaian kepuasan perkawinan ibu yang masih rendah yaitu dimensi keluarga dan teman. Hasil penelitian menunjukkan bahwa ibu masih kurang dalam menyesuaikan diri dengan mertua dan ipar. Penyesuaian ini seharusnya dilakukan karena adanya perbedaan latar belakang budaya, minat, dan usia sehingga pasangan harus belajar untuk memahami mertua dan ipar. Hal ini sejalan dengan pernyataan Wiliams, Sawyer, dan Wahlstrom (2006) bahwa seiring waktu kebersamaan yang terjalin dengan kerabat dari pihak masing-masing pasangan seperti mertua dan ipar turut berpengaruh terhadap kepuasan perkawinan.

Orientasi religius merupakan capaian paling tinggi pada kepuasan perkawinan ibu. Orientasi religius memiliki peran dalam kepuasan perkawinan karena orientasi religius seseorang dapat memengaruhi pola pikir dan perilakunya dalam menjalani kehidupan pernikahan. Hal ini disebabkan karena pernikahan merupakan sebuah proses adaptasi, dan agama dapat memfasilitasi dan menjadi sumber kekuatan 
dalam suatu hubungan. Beberapa studi juga telah banyak menyebutkan bahwa adanya hubungan yang positif antara religiusitas dengan kepuasan perkawinan (Dudley \& Kosinski, 1990; Filsinger \& Wilson, 1984; Oluwole \& Adebayo, 2008; Ardhianita \& Andayani, 2004). Hal ini juga didukung Mahoney (1999) diacu dalam Bradburry, Fincham, dan Beach (2000) yang menyatakan adanya korelasi positif antara kepuasan perkawinan dengan partisipasi religius. Kepuasan perkawinan dapat diprediksi dengan semakin baiknya ibadah keluarga, orientasi religius yang sesuai dengan pasangan, dan kedatangan ke tempat ibadah.

Selanjutnya, rata-rata capaian kepuasan perkawinan ibu yang juga tinggi yaitu kesetaraan peran. Hal ini sesuai dengan pernyataan istri yang merasakan kepuasan adalah apabila istri dapat memenuhi perannya dalam mengerjakan tugas rumah tangga, dan di lain pihak suami juga berpartisipasi dalam mengerjakan tugas rumah tangga (Khwaja \& Habib, 2007). Kesetaraan peran dapat berlangsung dengan baik apabila ada pembagian peran di dalam keluarga. Sesuai dengan pernyataan Puspitasari, Puspitawati, dan Herawati (2013) bahwa pembagian peran dan kotribusi anggota keluarga sangat dibutuhkan untuk menjaga keseimbangan dalam menjalankan fungsi keluarga menuju terwujudnya tujuan keluarga. Suami dan istri bersepakat dalam membagi peran dan tugas sehari-hari, bertanggung jawab terhadap peran dan tugasnya masing-masing, dan saling menjaga komitmen. Hal ini sejalan dengan Saginak (2005) yang menyatakan kepuasan perkawinan berhubungan dengan cara pasangan bernegosiasi untuk membagi tugas pekerjaan rumah, mencari nafkah, dan tanggung jawab antara suami dan istri.

Hasil analisis hubungan menemukan bahwa bahwa semakin lama pernikahan ayah dan ibu maka semakin baik tugas perkembangan keluarga. Hasil lain menemukan bahwa semakin lama pernikahan yang telah dijalani maka kepuasan perkawinan semakin meningkat. Hal ini sejalan dengan penelitian Glenn dan Weaver (1990) yang menemukan bahwa lama pernikahan memengaruhi kepuasan perkawinan seseorang. Penelitian Greenstein (1996) menemukan bahwa wanita yang masa pernikahannya semakin lama maka pernikahannya semakin stabil. Hasil penelitian ini tidak sejalan dengan hasil penelitian yang dilakukan oleh Rini \& Retnaningsih (2007) bahwa pasangan yang menikah di bawah lima tahun memiliki kepuasan perkawinan yang lebih tinggi dibandingkan dengan yang menikah di atas lima tahun. Hal ini mungkin dapat disebabkan pasangan yang baru menikah di bawah usia pernikahan lima tahun masih berada pada tahap awal perkawinan. Penelitian lebih awal menunjukkan bahwa kepuasan perkawinan memperlihatkan hasil yang tidak konsisten, maka masih ada hal-hal yang diperdebatkan dalam literatur-literatur tersebut (Clements \& Swensen, 2000). Penelitian yang dilakukan Burr (1970) menunjukkan bahwa pada saat mengalami penurunan dalam masa dua puluh tahun pertama setelah perkawinan kemudian akan meningkat kembali di tahuntahun berikutnya mengikuti kurva U. White, Booth, dan Edwards (1985) juga menemukan dalam penelitian mereka bahwa kepuasan perkawinan dialami paling tinggi pada saat awal pernikahan, lalu menurun secara bertahap di tahun-tahun selanjutnya. Penelitian Vaillant dan Vaillant (1993) juga menunjukkan bahwa lamanya pernikahan tidak cukup prediktif bagi munculnya kebahagiaan perkawinan yang dirasakan oleh para istri.

Hasil uji hubungan juga menemukan bahwa pasangan yang berpendidikan cenderung menciptakan equalitarian marriage, yaitu menciptakan kesempatan yang sama antara suami dan istri untuk bertanggung jawab. Hal ini sejalan dengan penelitian Glenn dan Weaver (1988), yang menjelaskan bahwa perbedaan tingkat pendidikan memengaruhi kemampuan individu dalam memenuhi kebutuhan, keinginan, dan aspirasinya. Hal ini berarti semakin tinggi pendidikan ibu semakin jelas wawasannya sehingga persepsi terhadap diri dan kehidupan pernikahannya menjadi semakin baik.

Sejalan dengan hasil uji hubungan, hasil uji regresi pada penelitian ini juga menegaskan pengaruh yang nyata dari tugas perkembangan keluarga yang terpenuhi dengan baik, baik pada dimensi anak dan orang tua, terhadap kepuasan perkawinan ibu. Hasil ini sesuai dengan pernyataan Kapinus dan Johnson (2003) yang menyatakan bahwa pemenuhan tugas perkembangan keluarga berhubungan positif dengan kepuasan perkawinan. Artinya, peningkatan tugas perkembangan keluarga yang dijalankan akan menyebabkan peningkatan kepuasan perkawinan dalam keluarga. Hal ini juga didukung oleh Rostami (2013) yang menyebutkan bahwa pemenuhan tugas perkembangan keluarga yang baik berhubungan dengan kepuasan perkawinan, dan kepuasan perkawinan yang baik akan memengaruhi kualitas hidup. Dalam penelitian ini tidak ada satupun dari variabel karakteristik 
keluarga yang berpengaruh terhadap kepuasan perkawinan. Hasil ini sejalan dengan penelitian Schmitt, Kliegel, dan Shapiro (2007) yang menyatakan variabel sosial ekonomi dan kepribadian memiliki sedikit peran dalam memprediksi kepuasan perkawinan. Temuan dari penelitian ini menegaskan besarnya peran variabel pemenuhan tugas perkembangan terhadap kepuasan perkawinan ibu pada keluarga dengan anak pertama di bawah usia dua tahun. Tugas perkembangan yang terpenuhi dengan baik pada awal-awal kehidupan keluarga akan mendorong ibu merasakan kehidupan pernikahan yang lebih puas. Kepuasan inilah yang kemungkinan menjadi penentu keberhasilan tugas perkembangan keluarga pada periode berikutnya.

\section{SIMPULAN DAN SARAN}

Hasil penelitian menunjukkan bahwa rata-rata capaian tertinggi pada tugas perkembangan keluarga dimensi orang tua yaitu berbagi tanggung jawab dengan suami, sedangkan pada dimensi anak yaitu belajar mengetahui, bagaimana, dimana dan kapan terjadi eliminasi. Lebih lanjut, hasil penelitian juga menemukan bahwa capaian tertinggi dimensi kepuasan perkawinan ibu yaitu pada dimensi orientasi religius dan capaian terendah adalah pengelolaan keuangan. Hasil penelitian menegaskan bahwa semakin baik keluarga dalam memenuhi tugas perkembangan keluarga maka semakin tinggi kepuasan perkawinan yang dimiliki oleh ibu. Peningkatan pemenuhan tugas perkembangan dimensi orang tua dan dimensi anak secara konsisten berpengaruh nyata terhadap peningkatan kepuasan perkawinan ibu dari keluarga dengan anak pertama berusia di bawah dua tahun.

Berdasarkan hasil penelitian terdapat beberapa saran yang dapat diberikan, yaitu istri harus memiliki waktu berdua dengan suami, saling menghargai dan menjaga komitmen satu sama lain, dan membangun komunikasi yang baik dengan suami agar tetap romantis. Selain itu, dalam pengelolaan keuangan, untuk meningkatkan kepuasan perkawinan ibu maka keluarga dapat mengurangi pengeluaran belanja dan mencatat pemasukan dan pengeluaran keluarga setiap bulan, atau mencari alternatif untuk meningkatkan pendapatan keluarga. Peran yang cukup besar dari pemenuhan tugas perkembangan keluarga terhadap kepuasan perkawinan ibu pada awalawal kehidupan pernikahan mengindikasikan pentingnya pendidikan pranikah bagi calon pasangan suami istri untuk dapat lebih baik dalam menyiapkan tugas perkembangan keluarga yang harus dipenuhi. Selain itu, untuk penelitian selanjutnya, kepuasan perkawinan yang dalam penelitian ini hanya mengukur dari sisi istri dapat diperkaya dengan menyandingkannya dengan ukuran kepuasan perkawinan suami.

\section{DAFTAR PUSTAKA}

Ardhianita, L., \& Andayani, B. (2004). Kepuasan pernikahan ditinjau dari bepacaran dan tidak berpacaran. Jurnal Psikologi, Fakultas Psikologi Universitas Gajah Mada, 32(2), 101-111.

Bradburry, T. N., Fincham, F. D., \& Beach, S. R. H. (2000). Research on the nature and determinants of marital satisfaction: A decade in review. Journal of Marriage and the Family, 62, 964-980.

Burr, W. R. (1970). Satisfaction with various aspects of marriage over the life cycle. Journal of Marriage and the Family, 32, 29-37.

Clements, R., \& Swensen, C. H. (2000). Commitment to one's spouse as a predictor of marital quality among older couple. Current Psychology,19(2), 110120.

Dudley, M. G., \& Kosinski, F.A. (1990). Religiousity and marital satisfaction: A research note. Review of Religious Research, 32, 78-86.

Duvall, E. M. (1971). Family Development. Ed ke-4. New York, US: JB Lippincott Company.

Filsinger, E., \& Wilson, M. R. (1984). Religiosity, socioeconomic rewards, and family development: Predictor of marital adjusment. Journal of Marriage and Family, 46(3), 663-670.

Forste, R., \& Fox, K. (2008). Gender roles, household labor, and family satisfaction: a cross-national comparioson. Bringham Young University: Departement of Sociology.

Fower, B. J., \& Olson, D. H. (1993). ENRICH marital satisfaction scale: a brief research and clinical tool. Journal of Family Psychology, 7(2), 176-185.

Glenn, N. D., \& Weaver, C. N. (1988). The changing relationship of marital status to reperted happiness. Journal of Marriage and the Family, 50, 317-324. 
(1990). Quantitative research on marital quality in the 1980's: A crritical review. Journal of Marriage\& The Family, 52(4), $818-832$.

Greenstein, T. N. (1996). Gender ideology and perceptions of the fairness of the division of household labor: Effect on marital quality. Social Forces, 74.

Guerrero, L. K., \& Mongeau, P. A. (2008). On becoming "more than friends": The transition from friendship to romantic relationship. S. Sprecher, J. Harvey, editor. Handbook of relationship initiation. New York, US: Psychology Press, 175194.

Hawkins, J. L. (1968). Associations between companionship, hostility and marital satisfaction. Journal of Marriage and the Family, 30, 647-650.

Hoffman, L. W. (1984). Maternal employment and the young child. Perlrnutter M, editor. Parent-child interaction and parent-child relations in child development, Hilladale, NJ: Ertbaum, 101-27.

Hurlock, E. B. (1999). Psikologi perkembangan: Suatu pendekatan sepanjang rentang kehidupan edisi ke-5. Jakarta, ID: Penerbit Erlangga.

Kapinus, C. A., \& Johnson, M. P. (2003). The utility of family life cycle as a theoretical and empirical tool commitmen and family life-cycle stage. J Family Issues, 24(2), 155-184.

Khwaja, M., \& Habib, R. R. (2007). Husband's involment in housework and women's psychological health: findinng from a population-based study in Lebanon. American Journal of Public Health, 97(5), 860-866.

McCabe, M. K., \& Barnett, D. (2000). The relation between familial factors and the future orientation of urban, african american sixth graders. Journal of Child and Family Studies, 9(4), 91-508.

Meliani, F., Sunarti, E., \& Krisnatuti, D. (2014). Faktor demografi, konflik keluarga, dan kepuasan perkawinan istri bekerja. Jur. IIm. Kel. \& Kons., 7(3). 133-142.

Oluwole., \& Adebayo, D. (2008). Marital satisfaction: Connections of self- disclosure, sexual self-efficacy, and spiritual among nigerian women. Pakistan journal os social sciences, 5(5), 464-469.

Puspitasari, N., Puspitawati, H., \& Herawati, T. (2013). Peran gender, kotribusi ekonomi perempuan dan kesejahteraan keluarga petani holtikura. Jur. IIm. Kel. \& Kons., 6(1), 10-19.

Rini, Q. K., \& Retnaningsih. (2007). Kontribusi self disclosure pada kepuasan perkawinan pria dewasa awal. Jurnal Psikologi, 2(12), 157-163.

Roach, A. J., Frasier, L. P., \& Bowten. (1981). The marital scale. Journal of The Family, 42, 537-545.

Rostami, A. (2013). Marital satisfaction in relation to social support, coping, and quality of life in medical staff in Tehran, Iran (Tesis). Umea University, Sweden.

Saginak, K. (2005). Balancing work and family: Equity, gender, and marital satisfaction. The Family Journal, 11(10).

Schmitt, M., Kliegel, M., \& Shapiro, A. (2007). Marital interaction in middle and old age: A predictor of marital satisfaction. International Journal Aging and Human Development, 65(4), 283-300. doi:10. 2190/AG.65.4.a.

Schoen, R., Astone, N. M., Rothert, K., Standish, N. J., \& Kim, Y. J. (2002). Women employment, marital happiness and divorce. Social Forces, 81(2), 643662.

Vaillant, C. O., \& Vaillant, G. E. (1993). Is the U-curve of marital satisfaction an illusion? A 40-year study of marriage. Journal of Marriage and the Family, 55, 230-239.

Wiliams, B. K., Sawyer, S. C., \& Wahlstrom, C. M. (2006). Marriages, families, and intimate relationships: $A$ practical introduction. Boston: Pearson Education, Inc.

White, L. K., Booth, A., \& Edwards, J. N. (1986). Children and marital happiness: why negative correlation. Journal of Family Issues, 7, 131-147.

Zainah, A. Z., Nasir, R., Ruzy, S. H., \& Noraini, M. Y. (2012). Effect of demographic variables on marital satisfaction. Asian Social Science, 8(9). 